\title{
IMPELEMENTASI STRATEGI PEMERINTAH DESA KARANGREJO KECAMATAN ARJOSARI KABUPATEN PACITAN DALAM PENGEMBANGAN OBJEK WISATA AIR HANGAT TIRTO HUSODO
}

\author{
Mufti Karim Rifai ${ }^{1}$, Nur Kholis ${ }^{2}$, Dian Suluh Kusuma Dewi ${ }^{3}$ \\ 1,2,3 Program Studi Ilmu Pemerintahan, Fakultas Ilmu Sosial dan Ilmu Politik, Universitas \\ Muhammadiyah Ponorogo \\ 1,2,3 J1. Budi Utomo No.10 Ponorogo 63471 Jawa Timur Indonesia \\ ${ }^{1}$ Email : karimrifai.9b@gmail.com \\ ${ }^{2}$ Email: kholiswarwer5@gmail.com \\ ${ }^{3}$ Email: suluh.dian@gmail.com
}

\begin{abstract}
ABSTRAK
Objek wisata Air Hangat Tirto Husodo berada di 15 kilo meter dari Kabupaten Pacitan atau tepatnya di Desa Karangrejo, Kecamatan Arjosari, Kabupaten Pacitan. Kondisi lalu lalang kendaraan yang melewati jalur di sekitar objek wisata tersebut memang dapat dibilang minim, serta tidak ada angkutan umum, sehingga para wisatawan yang berkunjung ke wisata Air Hangat Tirto Husodo harus menggunakan kendaraan sendiri. Penelitian ini menggunakan pendekatan kualitatif dengan teknik pengumpulan data; observasi, wawancara dan dokumentasi. Informan dalam penelitian ini adalah pemerintahan desa ataupun jajaran nya serta pengelola wisata dan pengunjung yang datang ke wisata tersebut. Tujuan dari penelitian ini adalah untuk mengetahui sejauh mana pelaksanaan implementasi strategi pemerintah Desa Karangrejo terkait pengembangan objek wisata Air Hangat Tirto Husodo, sehingga dapat meningkatkan daya tarik serta tambahan penghasilan untuk kepentingan Desa.
\end{abstract}

Kata Kunci : Strategi, Pengembangan, Obyek wisata

\section{ABSTRACT}

Tirto Husodo Hot Spring Tourism object is located 15 kilometres from Pacitan Regency or precisely in Karangrejo Village, Arjosari District, Pacitan Regency. The condition of passing vehicles passing through the lanes around these attractions is indeed practically minimal, and there is no public transportation, so tourists visiting the Tirto Husodo Hot Springs tour must use their vehicles. This research uses a qualitative approach with data collection techniques; observation, interview and documentation. The informants in this study are the village government or its ranks as well as tour managers and visitors who come to the tour. The purpose of this research is to find out the extent of the implementation of the Karangrejo Village government strategy related to the development of the Tirto Husodo Hotspring attraction, to increase attractiveness and additional income for the benefit of the Village.

Keywords: Strategy, Development, Tourism site 


\section{AoEJ: Academy of Education Journal \\ Vol. 11 No 1 Tahun 2020}

\section{PENDAHULUAN}

Sektor pariwisata merupakan salah satu faktor yang penting bagi bergeraknya roda perekonomian serta pemerintahan di Indonesia. Hal ini sangat rasional apabila dikaitkan dengan keadaan maupun tata letak geografis dari Indonesia sendiri, dimana banyak dikelilingi oleh hutan, laut, maupun pegunungan. Secara tidak langsung Indonesia memiliki ragam potensi yang menjanjikan, baik dalam skala lokal maupun mancanegara. Menurut (Qadarrochman, 2010) sejatinya sumber pendapatan pemerintah diperlukan untuk mengimbangi beban pengeluaran pemerintah yang rutin dilakukan. Selain itu, penerimaan pemerintah dapat dibedakan atas dua bentuk, yakni penerimaan pajak dan non-pajak.

Dalam hal ini keuntungan yang di dapat dari sector pariwisata adalah salah satu sumber pendapatan yang biasanya terikat dengan pajak dari berbagai jalinan kemitraan yang telah dibangun seperti pajak hotel, pajak restoran, pajak iklan, pajak reklame, pajak retribusi, dan sebagainya. Walaupun pariwisata sendiri memang merupakan hal yang identik dengan memanjakan mata, sehingga tak heran jika seluruh daerah telah melakukan upaya yang serius dalam mengembangkan spot pariwisata di daerahnya masing-masing. Selain meningkatkan estetika keindahan dari objek ataupun pemanfaatan alam bebas, di sisi lain sektor pariwisata juga mampu untuk meningkatkan Pendapatan Asli Daerah (PAD) hingga pada devisa Negara secara keseluruhan.

Air Hangat Tirto Husodo merupakan sector pariwisata yang bertempat di Kabupaten Pacitan Jawa Timur. Spot Wisata Air Hangat Tirto Husodo dapat dikatergorikan dalam tahapan yang masih awal, karena sangat minim pengembangan dan minat pengunjung. Dalam hal ini jika dilihat secara luas, maka dapat dimunculkan sebuah analisa bahwa kurangnya minat masyarakat dapat disebabkan oleh banyak faktor/selera. Ditambah lagi identitas Pacitan yang sudah terlanjur dikenal sebagai kota "1001 goa", serta pesona lepas pantai yang telah lebih dahulu dikembangkan secara bertahap. Sedangkan kemungkin yang lain adalah lebih kepada ide serta inovasi dari pemerintah setempat, dimana memerlukan konsep serta strategi dalam pelaksanaanya.

Hal ini sejalan dengan pernyataan (Manafe et al., 2016) bahwa promosi objek wisata alam, wisata buatan, seni, maupun budaya di daerah memang memiliki tantangan serius untuk diimplementasikan, atau dengan kata lain tidak semudah memasarkan suatu produk kecil perusahaan (misalnya roti, minuman, pakaian). Apalagi dengan promosi objek wisata di tingkat 


\section{AoEJ: Academy of Education Journal \\ Vol. 11 No 1 Tahun 2020}

Desa, sangat diperlukan kerangka otonomi yang jelas, serta juga harus memiliki kesadaran untuk mengoptimalkan potensi wisata yang dimiliki dengan sentuhan ide-ide kreatif.

Artinya secara garis besar, adanya sektor parisiwata juga bisa disebut sebagai sebuah upaya pembangunan yang sifatnya kontinyu, serta dapat menerima pembaruan maupun inovasi. Secara umum, kualitas pariwisata dapat dilihat dari berbagai faktor penyangga maupun dari seberapa besar antusias masyarakat (lokal \& mancanegara). Hukumnya adalah bahwa stimulus dapat dicapai apabila suatu objek wisata tidak bersifat ajeg (stagnan), apalagi jika objek wisata tersebut berada di tingkat Desa. Karena tentunya hal ini menjadi variable tambahan, bagi penggodokan konsep, ide, maupun inovasi.

Pengembangan pariwisata yang telah dilakukan dengan baik oleh pemerintah maupun melalui jalinan kemitraan dengan pihak swasta, sejatinya adalah bagian dari strategi guna meningkatkan jumlah kedatangan para wisatawan. Timbal baliknya, kunjungan wisatawan akan bergesekan dan memicu interaksi sosial dengan penduduk di sekitar tempat wisata. Serta merangsang tanggapan masyarakat sekitarnyasesuai dengan mobilitas yang dilakukan oleh wisatawan, sepanjang kemanapun mereka berusaha untuk melakukan adaptasi dalam lingkup perekonomian, kemasyarakatan mau- pun kebudayaan (Soebagyo, 2012).

Maka dari itu, adanya pemerintah merupakan suatu penggerak yang memiliki kendali terhadap arah pengembangan yang akan dituju. Walaupun tidak menutup kemungkinan bahwa pemerintah juga dapat membuka ruang kerjasama dengan pihak swasta, namun tetap yang memiliki kewenangan dalam mengatur serta membuat kebijakan adalah pemerintah sendiri. Maka dari itu, penelitian ini bertujuan untuk mengetahui sejauh mana strategi pengembangan yang dilakukan oleh Pemerintah Desa Karangrejo terhadap objek wisata Air Terjun Tirto Husodo

di Kecamatan Arjosari Pacitan. Dimana berdasarkan kesimpulan sementara, objek wisata ini belum disokong dengan fasilitas-fasilitas penunjang yang memadai.

\section{METODE PENELITIAN}

Jenis penelitian ini menggunakan metode deskriptif kualitatif, dengan fokus utama adalah tentang apa yang telah dibuat, dirancang, ataupun dipelihara oleh pemerintah Desa Karangrejo terhadap pengembangan objek wisata Air Hangat Tirto Husodo. Kemudian metode pengolahan dan pengumpulan data adalah dengan cara melakukan wawancara tidak terstruktur kepada 


\section{AoEJ: Academy of Education Journal \\ Vol. 11 No 1 Tahun 2020}

beberapa wisatawan (pengunjung), serta melakukan observasi langsung ke objek penelitian. Kemudian, melakukan dokumentasi untuk melengkapi data.

Adapun tekhnik analisis data dalam penelitian ini adalah menggunaan metode interaktif, yakni (reduksi data, penyajian, dan kesimpulan). Hal ini dilakukan karena jawaban dari para wisatawan cenderung monoton, sehingga memerlukan metode reduksi data untuk memperjelas narasi yang hendak dibangun. Tujuanya adalah untuk memudahkan proses penyajian data, agar terlihat lebih efektif untuk dilihat.

\section{HASIL DAN PEMBAHASAN}

\section{Definisi Pariwisata}

Menurut Spilane dalam (Soebagyo, 2012) pariwisata adalah perjalanan dari suatu tempat ke tempat lain yang ada di seluruh pelosok bumi, lalu sifatnya adalah sementara/temporer tergantung pada seberapa besar selera maupun keinginan, serta dilakukan secara individu maupun bergerombol/berkelompok.

Masih menurut Spilane dalam (Soebagyo, 2012) bahwa perjalanan pariwisata ini dapat dimaknai sebagai usaha untuk mencari titik keseimbangan, keserasian, kesenangan, dengan lingkungan hidup yang baru (diluar habitat), dan memiliki resiko untuk bersentuhan langsung dengandimensi yang ada seperti : sosial, budaya, alam, maupun keilmuan”. Ditambah pula bahwa pariwisata terbagi atas beberapa jenis, yaitu:

(1) pariwisata untuk menikmati per- jalanan (pleasure tourism);

(2) pariwisata untuk berekreasi (recreation tourism);

(3) pariwisata untuk budaya (culture tourism);

(4) pariwisata untuk olah raga (sport tourism);

(5) pariwisata untuk urusan usaha dagang (business tourism); dan

(6) pariwisata untuk berkonvensi (conventional tourism).

Menurut (Nurmi, 2014) jenis-jenis pariwisata terbagai ke dalam tiga yaitu :

a) Wisata Budaya: wisata ini merupakan objek yang dijadikan masyarakat sebagai pembelajaran terhadap keadaan rakyat, kebiasaan, maupun adat istiadat.

b) Wisata Alam: merupakan wisata yang mengandung mineral atau tempat untuk penyembuhan, maupun tempat yang memiliki fasilitas lainya.

c) Wisata Kuliner: Wisata yang di dalamnya terdapat makanan khas dari daerah tersebut. 


\section{AoEJ: Academy of Education Journal \\ Vol. 11 No 1 Tahun 2020}

Sementara itu menurut pendapat Pendit dalam (Soebagyo, 2012), menjabarkan dengan singkat bahwa pariwisata merupakan suatu sektor yang memiliki tingkat kompleksivitas tertentu, karena sangat dimungkin atau bahkan dapat dipasitikan untuk melibatkan industriindustri rumahan, seperti olahan kerajinan tangan,kreasi cinderamata, serta usaha-usaha penginapan,, restoran dan transportasi di kemudian hari dan dalam jangka waktu yang lama. Baik antar pihak pengembang maupun pihak pendukung, akan sama-sama memiliki prospek keuntungan.

\section{Definisi Pengembangan Pariwisata}

a) Menurut Joyosuharto (Soebagyo, 2012) pengembangan pariwisata memiliki tiga gagasan utama yang berorientasi pada keseimbangan antara pihak-pihak terkait, diantaranya adalah sebagai berikut :

1) Menghidupkan roda perekonomian antar warga masyarakat, pemerintah, dan pengusaha;

2) Memelihara kepribadian bangsa dan kelestarian fungsi dari usaha-usaha untuk merawat \& meningkat mutu lingkungan hidup;

3) Memupuk rasa cinta tanah air dan bangsa, melalui kebanggaan terhadap wisata alam buatan maupun pengembangan.

b) Menurut Sunaryo (2013) pengembangan suatu kawasan maupun objek wisata, harus dibarengi dengan besarnya partisipasi masyarakat. Selain masyarakat, peran maupun kontribusi dari pengembang dan pemerintah juga menjadi sangat vital, sehingga ketiganya tidak dapat dipisahkan (Lutpi, 2016).

c) Menurut (Sefira Ryalita Primadany, Mardiyono, 2013) sektor kepariwisataan memerlukan strategi dan pola pengembangan yang terencana, agar mampu dikembangkan secara opimal, serta peran pemerinta adalah sebagai agen penggerak yang utama.

d) Menurut (Amalyah et al., 2016) pembangunan pariwisata dilakukan untuk meningkatkan pendapat (devisa negara), dan hal ini akan memberikan dampak yang secara tidak langsung diterima oleh masyarakat karena mereka memiliki kesempatan membuka lapangan pekerjaan.

e) Menurut (Prasodjo, 2017) analisis publik sangat dibutuhkan untuk mengembangkan suatu objek maupun kawasan wisata, karena dengan pemahaman tersebut maka akan 
tercipta pelayanan yang baik dan mampu untuk menarik minat wisatawan yang bisa berasal dari wisatawan local atau mancanegara.

Kelima poin diatas, merupakan suatu gambar besar yang tidak asing lagi untuk dikaji. Karena ada arah dan tujuan yang jelas, serta lahirnya pembagian peran antar pihak. Siklusnya yakni : ada yang memiliki modal, ada yang memiliki ide kreatif untuk mengembangkan, ada yang ikut melengkapi guna meningkatkan daya tarik dan minat wisatawan dengan cara-cara tertentu. Hal yang jelas dan pasti adalah keseluruhan perbedaan peran diatas tentu tidak lepas dari kesamaan dalam mencapai tujuan, dan mampu untuk terus bertahan hidup dengan mengandalkan upaya serta usaha melalui sector pariwisata dan pola kerjasama yang selalu dilakukan.

Pada umumnya, produk yang ditawarkan melalui sector pariwisata adalah berupa pelayanan, dalam arti lain adalah segala sesuatu yang dapat dirasakan dan diukur melalui kepuasan, tetapi tidak berwujud. Pariwisata mengemas produk yang berwujud dan tidak berwujud menjadi suatu kesatuan utuh (Addin Maulana, 2016). Maka dari itu, disini dapat ditarik satu penyataan bahwa sektor pariwisata memerlukan upaya pengembangan yang orientasinya harus disesuaikan dengan membaca minat masyarakat. Karna hal ini tidak mudah, tentunya suatu upaya pengembangan harus dibarengi dengan langkah identifikasi serta perumusan terhadap konsep yang hendak diimplementasikan.

\section{Penerapan Strategi Pengembangan (Objek Wisata Air Hangat Tirto Husodo)}

Dalam sub bab ini, akan dijelaskan mengenai seberapa jauh implementasi strategi dari Pemerintah Desa Karangrejo dalam mengembangkan objek wisata Air Hangat Tirto Husodo.Maksudnya adalah lebih kepada melakukan observasi terhadap segala pembangunan maupun fasilitas penunjang yang memang telah dilakukan sejak awal peresmian. Tentunya pemerintah Desa Karangrejo memiliki koridor yang jelas dalam melakukan pengembangan, karena dibekali dengan ruang untuk melakukan otonomi di tingkat desa sehingga hal ini menjadi pemicu untuk terus berrinovasi. Diantaranya adalah sebagai berikut :

\section{a) Pemberlakuan Sistem Open 24 Jam}

Data ini berdasarkan dari hasil observasi secara langsung, serta juga hal ini sudah menjadi ketentuan umum sehingga banyak orang tahu, Sebagai contoh adalah media online Kompas melalui (Prasetya, 2019) yang telah meliput dan mempublikasikan kepada publik. 


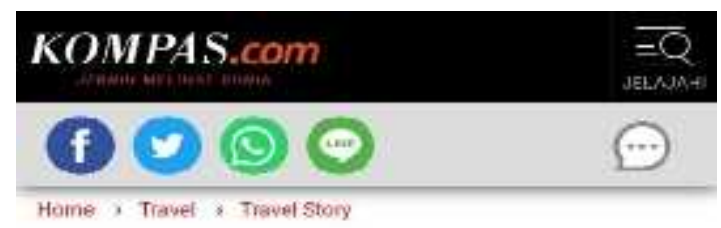

\section{Pacitan Punya Pemandian Air Hangat Alami 24 Jam}

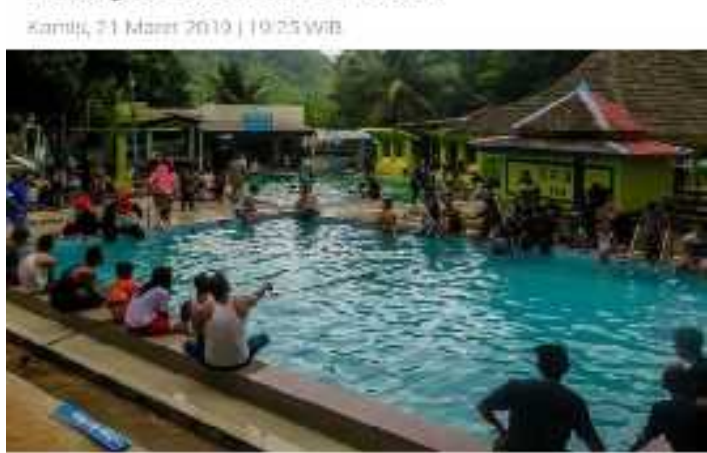

Gambar 1. Sosialisasi melalui media online (kompas.com)

Hal ini merupakan sebuah terobosan yang bisa dibilang istimewa, karena pemerintah Desa Karangrejo telah membuka akses sebesar-besarnya bagi masyarakat agar bisa datang sewaktu-waktu.

\section{b) Fasilitas Gubuk Semi Modern}

Fasilitas penunjang ini dapat ditemui di sekitar pemandian air panas, karena hal ini difungsikan sebagai sarana untuk berteduh, beristirahat, berbincang, melindungi tubuh dari hujan maupun panas, dsb. Tentunya hal ini juga dapat dikategorikan sebagai implementasi strategi dari pemerintah Desa Karangrejo, guna memperhatikan mood dan menumbuhkan kesan positif yang dapat dirasakan oleh para pengunjung.

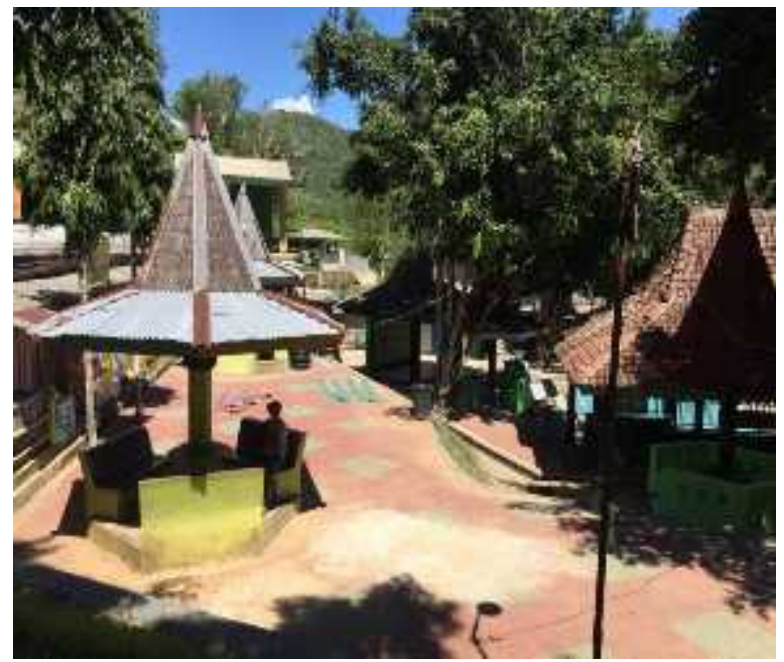

Gambar 2. Lokasi sekitar obyek wisata 


\section{c) Sarana Peribadatan (Masjid)}

Dibangunya sarana ibadah bagi umat muslim ini, bukan berarti bahwa pemerintah Desa Karangrejo telah bersikap tendensi terhadap umat lain. Akan tetapi ini disesuaikan dengan kuantitas pengunjung yang kebanyakan beragama Islam. Pemerintah tentunya yakin dengan pengunjung yang tidak beragama islam, maksudnya adalah yakin bahwa mereka yang non-islam pasti sudah mampu untuk mengkondisikan diri dalam hal melaksanakan beribadah. Baik umat Kristen, Hindu, dan Budha memang biasanya melakukan ibadah pada hari-hari tertentu saja. Berbeda dengan umat islam, yang ketentuan ibadahnya adalah setiap hari dalam 5 waktu.

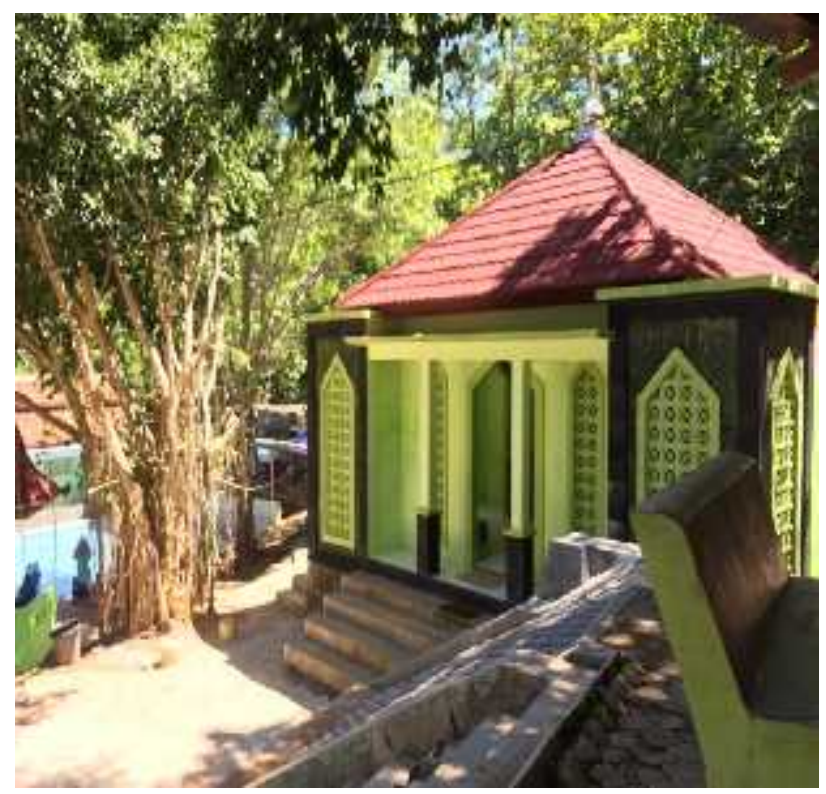

Gambar 3. Sarana masjid di sekitar obyek wisata

\section{d) Kesediaan Lahan Parkir}

Di objek wisata ini lahan parkirnya telah diperluas dari awal mula nya, sehingga kendaraa para wisatawan terkondisikan dengan baik. Hal ini merupakan sesuatu yang dapat dimaklumi, seiring dengan minat wisatawan semakin besar setiap hari nya seperti di tempat-tempat wisata lain (walau belum setara jika dibandingkan).

Sesuai dengan fakta yang ada, objek wisata Air Hangat Tirto Husodobiasanya mengalami puncak keramaian pada moment lebaran dan liburan anak sekolah. Maka dari itu, peran pemerindah desa dalam mengkondisikan lahan parkir adalah hal yang penting karena potensi konflik dan gesekan bisa saja muncul antar para wisatawan yang berebut lahan. 


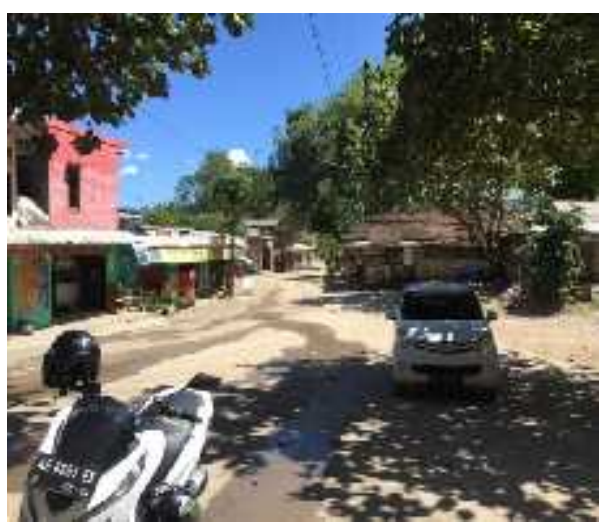

Gambar 4. Lahan parkir

\section{e) Kolam Pemandian yang Terpisah Antara Dewasa \& Anak-anak}

Pembuatan kolam yang terpisah ini merupakan suatu langkah yang mengedepankan keamanan bagi para pengunjung di bawah umur. Kemudian hal ini juga mampu untuk menghilangkan rasa was-was dari para orang tua agar tidak terlalu mengkhawatirkan anaknya.

Tidak dapat dipungkiri, betapa banyak anak-anak yang tewas akibat dari kelalaian orang tua mereka, ketika berada di tempat-tempat yang rawan seperti : di kolam renang, eskalator mall, laut, dsb. Pembangunan kolam terpisah ini dapat dikategorikan sebagai prinsip antisipatif dan kehati-hatian, juga sebagai bentuk tanggung jawab yang melekat pada pemerintah Desa Karangrejo selaku pengelola.

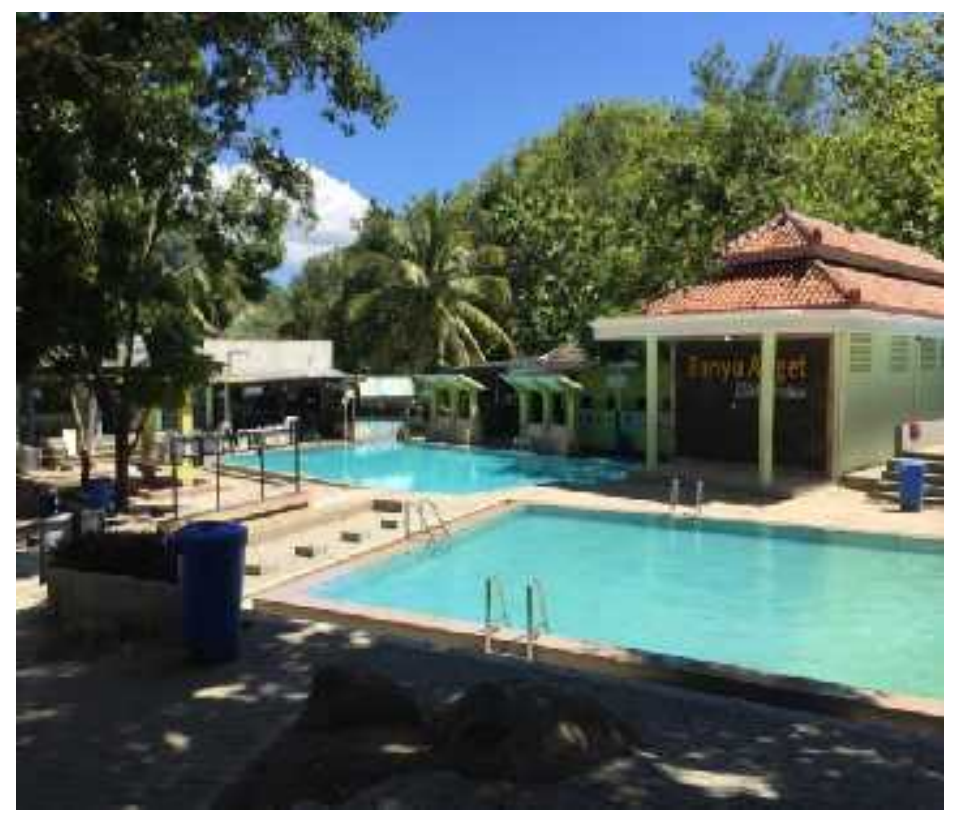

Gambar 5. Lokasi wisata Air Hangat Tirto Husodo 


\section{AoEJ: Academy of Education Journal \\ Vol. 11 No 1 Tahun 2020}

\section{SIMPULAN}

Pengembangan Objek Wisata Air Hangat Tirto Husodo merupakan salah satu bukti bahwa Kabupaten Pacitan tidak hanya identik dengan wisata goa maupun pantai lepas. Hal ini dapat dimaknai sebagai suatu kemajuan yang mampu mendongkrak sector-sektor kepariwisataan di daerah, terurama di desa lain. Objek Wisata Air Hangat Tirto Husodo yang ada di Desa Karangrejo Kecamatan Arjosari, telah membawa sedikit perubahan bagi kehidupan warga sekitar. Mulai dari interaksi sosial, transaksi jual beli, maupun pola komunikasinya. Keseluruhan relasi antara warga masyarakat dengan para pengunjung (wisatawan), adalah satu efek positif dari adanya pembangunan yang dilakukan. Maka dari itu, dapat disimpulkan bahwa semakin pemerintah Desa Karangrejo akan selalu focus untuk lebih memantapkan konsep ini ke depanya, untuk tujuan meningkatkan citra serta lebih menarik minat wisatawan.

Adapun implementasi strategi yang dilakukan oleh pemerintah desa Karangrejo diantaranya adalah melakukan sosialisasi pada masyarakat terkait jam kunjung 24 jam melalui media online dan melakukan pembangunan fasilitas penunjang bagi wisatawan yakni pembangunan masjid, melengkapi fasilitas gubuk di sekitar pemandian, lahan parkir yang bersih dan luas, serta membangun kolam terpisah bagi anak-anak dan dewasa.

\section{SARAN}

Pemerintah Desa Karangrejo harus lebih menjalin kerjasama dengan pihak yang menguntungkan dan menemukan ide-ide baru, untuk melakukan pengembangan Objek Wisata Air Hangat Tirto Husodo agar estetika keindahannya lebih meningkat.

\section{DAFTAR PUSTAKA}

Addin Maulana. (2016). PENGARUH KUNJUNGAN WISATAWAN MANCANEGARA DAN PERJALANAN WISATAWAN NUSANTARA TERHADAP PENYERAPAN TENAGA KERJA SEKTOR PARIWISATA DI INDONESIA. Jurnal Kepariwisataan Indonesia, 11, 119-143.

Amalyah, R., Hamid, D., \& Hakim, L. (2016). Peran Stakeholder Pariwisata Dalam Pengembangan Pulau Samalona Sebagai Destinasi Wisata Bahari. Jurnal Administrasi Bisnis S1 Universitas Brawijaya, 37(1), 158-163.

Lutpi, H. (2016). Analisis tingkat partisipasi masyarakat dalam pengembangan pariwisata pantai di Kecamatan Jerowaru. Jurnal Program Studi Pendidikan Ekonomi, 8(3), 1-10.

Manafe, J. D., Setyorini, T., \& Alang, Y. A. (2016). PEMASARAN PARIWISATA MELALUI 


\section{AoEJ: Academy of Education Journal \\ Vol. 11 No 1 Tahun 2020}

STRATEGI PROMOSI OBJEK WISATA ALAM, SENI DAN BUDAYA (Studi Kasus di Pulau Rote NTT). Jurnal BISNIS, 1(1), 123.

https://www.academia.edu/37497039/PEMASARAN_PARIWISATA_MELALUI_STRATEGI_ PROMOSI_OBJEK_WISATA_ALAM_SENI_DAN_BUDAYA_Studi_Kasus_di_Pulau_R ote_NTT

Nurmi, H. (2014). Jurnal Edik Informatika Membangun Website Sistem Informasi Dinas Pariwisata Jurnal Edik Informatika. Jurnal Edik Informatik, 1(2), 1-6.

Prasetya, A. W. (2019). Pacitan Punya Pemandian Air Hangat Alami 24 Jam.

https://www.google.com/amp/s/amp.kompas.com/travel/read/2019/03/21/192500027/pacitanpunya-pemandian-air-hangat-alami-24-jam

Prasodjo, T. (2017). Pengembangan Pariwisata Budaya dalam Perspektif Pelayanan Publik. Jurnal Office, 3(1), 7. https://doi.org/10.26858/jo.v3i1.3448

Qadarrochman, N. (2010). Analisis Penerimaan Daerah Dari Sektor Pariwisata Di Kota Semarang Dan Faktor-Faktor Yang Mempengaruhinya. In Skripsi. Universitas Diponegoro.

Sefira Ryalita Primadany, Mardiyono, R. (2013). ANALISIS STRATEGI PENGEMBANGAN PARIWISATA DAERAH (Studi pada Dinas Kebudayaan dan Pariwisata Daerah Kabupaten Nganjuk). Jurnal Administrasi Publik (JAP), 1(4), 135-143.

Soebagyo. (2012). Strategi Pengembangan Pariwisata Lokal Di Indonesia. Jurnal Liquidity, 1, $153-158$. 